\title{
The Azure Jay may reproduce in plantations of Araucaria angustifolia in southern Brazil
}

\author{
ANDREA LARISSA BOESING and LUIZ DOS ANJOS
}

\begin{abstract}
Summary
We undertook field observations of the Azure Jay Cyanocorax caeruleus in Araucaria plantations and a secondary forest in southern Brazil from 2007 to 2010. During the breeding season, the territory and the flock sizes in Araucaria plantations (31.6-42.2 ha; 2-3 individuals) seemed to be smaller than in the secondary forest (64.5-72.6 ha; 5-6 individuals). One active nest was monitored in October-November 2009 and indicated cooperative breeding by the Azure Jay, as for the majority of American jays. The fact that reproduction was documented in Araucaria plantations may be positive for the conservation of this species, since natural areas of mixed rainforest are becoming increasingly scarce.
\end{abstract}

\section{Introduction}

The Azure Jay Cyanocorax caeruleus is the most endangered of the South American species in the Cyanocorax genus, and is classified as 'Near Threatened' (BirdLife International 20o8). Field observations have suggested that this species is undergoing a substantial decline in numbers, particularly in western areas of its range, where mixed rainforest (a type of southern temperate forest) occurs (Ridgely and Tudor 1989, Stotz et al. 1996, BirdLife International 2000). The Azure Jay population decline is probably caused by the fragmentation and degradation of this forest type (Anjos 1991).

The conifer Araucaria angustifolia (Bertol.) Kuntze is classified as 'Critically Endangered' (IUCN 2010) and comprises around $40 \%$ of the trees in mixed rainforest, with the result that the canopy is almost exclusively composed of this species (Schäffer and Prochnow 2002). The seed of A. angustifolia is quite important for the Azure Jay, which feeds almost exclusively this resource during most of the autumn and winter in mixed rainforest (Anjos 1991, Anjos et al. 2009). Besides severe fragmentation, mixed rainforest has been strongly degraded by human activities throughout its entire range, resulting in the almost complete suppression of the under- and mid-storeys, leaving only the canopy. Although A. angustifolia is protected by law, its seeds are extensively harvested for human consumption, with more than 3,00o tonnes being sold each year as an alternative income for poor families (Koch and Corrêa 2002). The timber of A. angustifolia has been extensively exploited (Koch and Corrêa 2002) and these two factors severely threaten this tree species. Only a few large natural areas of mixed rainforest remain, some of which are in nature reserves, but plantations of $A$. angustifolia are increasing (90,00o ha in the mid-1990s) thus reducing the pressure on this tree species if the ban on logging is effectively enforced (Backes 2009).

We undertook field observations of several flocks of Azure Jay breeding in plantations of A. angustifolia and in a secondary forest in southern Brazil to determine whether the plantations that are improving the conservation status of $A$. angustifolia could also be an effective conservation tool for Azure Jay. The aim of this study was to estimate the territory and flock sizes of Azure Jay in both habitats. We monitored one active nest in Araucaria plantations. 
Reproduction of the Azure Jay is poorly known, with only a few nests having been found and observed (Anjos 1991, Bornschein et al. 1996, Anjos et al. 2009).

\section{Methods}

\section{Study areas}

We studied Azure Jays at two localities in Santa Catarina state, southern Brazil (Figure 1A). Both localities are within the mixed rainforest (MF) zone, where the annual average temperature is ${ }^{13}-24{ }^{\circ} \mathrm{C}$, annual rainfall is $1,550 \mathrm{~mm}$, and there is no dry season (Morellato et al. 2000, Mendonça and Danni-Oliveira 2002). The first area is a reserve, the Floresta Nacional de Três Barras (FNTB; municipality of Três Barras; $26^{\circ} 13^{\prime} \mathrm{S}, 50^{\circ} 18^{\prime} \mathrm{W}$; Figure $1 \mathrm{~B}$ ), under the protection of the Brazilian government, it covers 4,458 ha and is mostly $(50 \%)$ occupied by old secondary forest. The remaining area of the FNTB is occupied by plantations of A. angustifolia (14\%) and

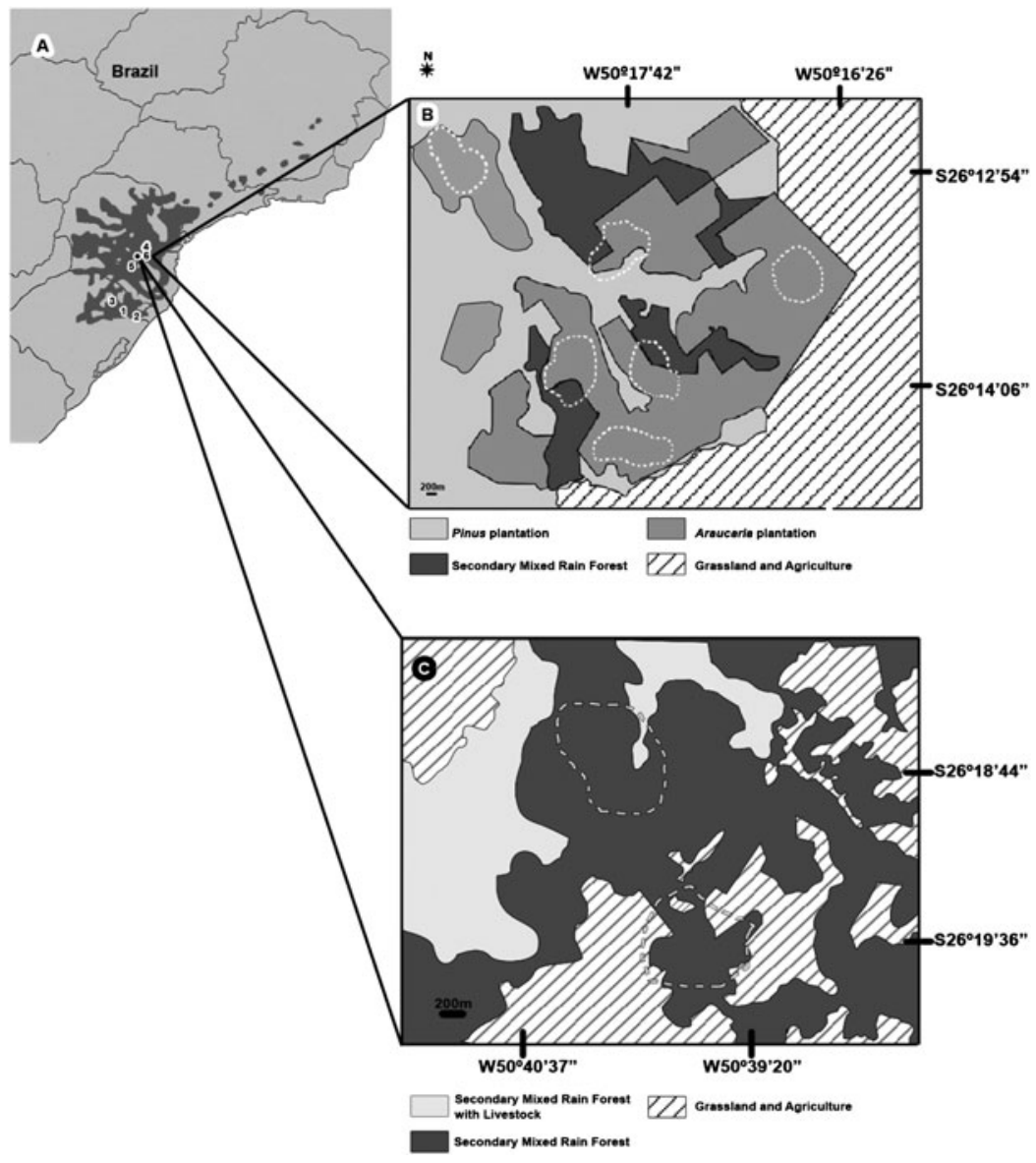

Figure 1. Azure Jay recordings, indicated by numbers 1-6, in MF and protected Araucaria plantations in southern Brazil (A); the territories (white dotted line) studied in plantations of Araucaria angustifolia in the Floresta Nacional de Três Barras Reserve (B), and flocks studied in the secondary forest of Fazenda Thomazzi (C) 
Pinus spp. (30\%), besides other land use (6\%). The area surrounding the FNTB is composed of disturbed areas (agriculture, pasture, and urban areas), but there is a young secondary forest used for military training in the south-eastern region. The second area is the Fazenda Thomazi (FTHO; municipality of Irineópolis, $26^{\circ} 19^{\prime} \mathrm{S}, 50^{\circ} 39^{\prime} \mathrm{W}$; Figure $1 \mathrm{C}$ ), located $37 \mathrm{~km}$ away from FNTB. The FTHO is a rural area 2,00o ha in size, which is composed of secondary forest used for livestock $(20 \%)$, secondary forest not used for livestock $(50 \%)$, and agriculture, mostly tobacco $(30 \%)$.

\section{Field observations and data analysis}

There were two types of field observations in the FNTB. In the first type (type 1 ), we searched for the Azure Jay in Araucaria plantations. We visited the study area each month (four consecutive days each month) during 2007. In the second type of observations (type 2), we mapped the territory of the observed birds and observed an active nest. This took a total of 36 days in the period September-November 2009. A total of 360 hours of field observations were undertaken in the FNTB, which began early in the morning each day. In the FTHO we only mapped the territories of the Azure Jay. In order to do this we visited the FTHO weekly (two days each week) in September-November 2010. We used binoculars $(8 \times 35)$ during the observations.

Transects were established in the FNTB and FTHO using the available roads and trails. During type 1 field observations in the FNTB we walked six transects of c. $\mathrm{km}$ in $\mathrm{I}$ h daily. Azure Jays were detectable up to $150 \mathrm{~m}$ on each side of the transects, which gave a sample area of c.180 ha. In type 2 observations in the FNTB, ten transects of c.1.5 km were walked each day at a speed of c. $1 \mathrm{~km} \mathrm{~h}^{-1}$, with a similar range of detection, thus surveying an area of c.40o ha. In FTHO, nine transects were also walked at a similar speed, giving a sample area of about 240 ha. We plotted on a map each Azure Jay flock we encountered within the transects (Luginbuhl et al. 2001). Based on these maps and taking into account the fact that American jays maintain an area of dominance around an active nest (see Anjos et al. 2009) we estimated the extent of the jays' territory using a minimum convex polygon (MCP; Mohr 1947, Odum and Kuenzler 1955), which consists of joining the outermost observation points for each bird with a straight line. The largest polygon obtained was taken as the territory size of the birds. Such a procedure was chosen due to its simplicity and wide use in ornithology (e.g. Jullien and Thiollay 1998, Wiktander et al. 2001, Ribeiro et al. 2002, Duca et al. 2006). We used linear regression (R Development Core Team 2009) to test the relationship between territory size and the number of individuals in the flocks. The names of the vocalisations mentioned in this study were based on a description of the vocal repertoire of the Azure Jay presented in Anjos and Vielliard (1993). A copy of the tape is deposited in the British Library of Wildlife Sounds, UK, and in the Bioacoustic Archive of the Florida State Museum, USA.

\section{Results}

The Azure Jay was not recorded in the surveyed plantations of Araucaria from January to August 2007. This species was first recorded in the plantations of FNTB in September 2007, and then throughout all of the following months of the field observations.

Six flocks were mapped in Araucaria plantations in the FNTB in September-November 2009, four containing three individuals and two with two individuals. Territories of three flocks in the FNTB were covered only by Araucaria plantations, another two also included small areas of native secondary mixed rainforest (about 30\% each) and the remaining included Araucaria plantations, native secondary mixed rainforest, and a small area (about $15 \%$ ) of Pinus plantations. We estimated the territory size in the FNTB as 38 ha (31.6-42.2 ha; Figure $1 B$ ). In FTHO we mapped two flocks, one of five individuals and the other of six individuals; their territory sizes were estimated as 64.5 and 72.6 ha, respectively (Figure $1 \mathrm{C}$ ). In both cases, the territories were predominantly composed of secondary forest, but with a high density of Araucaria trees. The 
density of Araucaria in all eight territories seemed to be similar. Regression analyses showed a significant relationship between territory size and the number of individuals $(F$ 1,6 $=69,68$; $P<0.001 ; r=0.92$; Figure 2).

In the FNTB we found and monitored one active nest of the Azure Jay. Three birds were watched at the same place in the plantation for two days at the beginning of October 2009. They made the social call and the social alarm call when they saw the observer, and flew 80-100 m away. We found a nest on 4 October 2009 which was $60 \mathrm{~m}$ away from the transect, at a height of $18 \mathrm{~m}$ and placed $\mathrm{I} \mathrm{m}$ below the top of a young A. angustifolia tree. Incubation started on 6 October and the incubation period lasted about 16 days. We observed the nestlings being fed on 22 October. We observed a second adult individual perched at the nest during $58 \%$ of the observed incubation time. These two birds stayed at the nest for $17 \mathrm{~min}$ (minimum) to $3 \mathrm{~h}$ (maximum). On three occasions it was clear that the individual at the nest had been replaced by the other. The bird that was incubating emitted a pair call to be fed by individuals of the flock. We observed a third individual working as a helper. This bird helped to feed both the bird that was incubating and the nestlings, besides performing sentinel activities.

\section{Discussion}

Mixed rainforest is now restricted to 3.2 million ha, about $12.6 \%$ of its original distribution, but only 98,121 ha are legally protected in reserves (Ribeiro et al. 2009). There are 72 reserves in the mixed rainforest zone, but only 56 are larger than 100 ha (Indrusiak and Monteiro 2009). There are nine reserves containing Araucaria plantations in southern Brazil and the Azure Jay was observed in Araucaria plantations in six of these (Table 1; Figure 1A). In one reserve (Floresta Nacional de Irati), Volpato et al. (2010) found that the abundance of the Azure Jay was higher in the Araucaria plantation than in primary mixed rainforest. In another reserve (Floresta Nacional de Passo Fundo) N. Prestes (pers. comm. 2010) also recorded breeding of Azure Jays in Araucaria plantations.

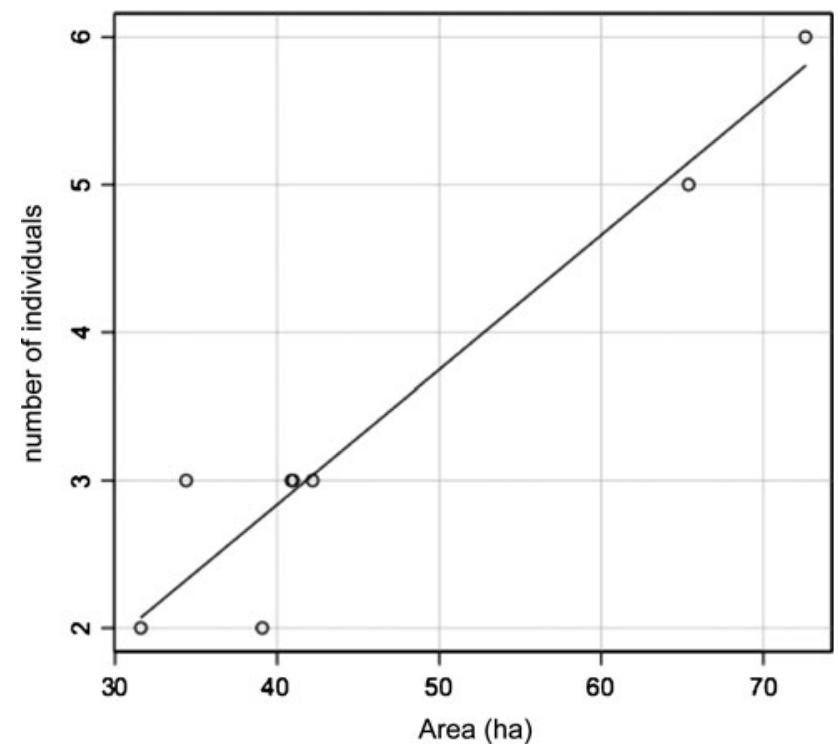

Figure 2. Relationship between territory size and the number of individuals in Azure Jay flocks during the breeding station in mixed rainforest (MF), southern Brazil. 
Table 1. Reserves with Araucaria plantations in the mixed rainforest (MF), Southern Brazil where Azure Jay was recorded over the last decade.

\begin{tabular}{lll}
\hline Reserves & Coordinates & Source \\
\hline 1 - Floresta Nacional de Canela & $29^{\circ} 18^{\prime} \mathrm{S} ; 50^{\circ} 53^{\prime} \mathrm{W}$ & Franz et al. 2004 \\
2 - Floresta Nacional de São Francisco de Paula & $29^{\circ} 25^{\prime} \mathrm{S} ; 50^{\circ} 23^{\prime} \mathrm{W}$ & Prestes 2010 (pers. comm.) \\
3 - Floresta Nacional de Passo Fundo* & $29^{\circ} 00^{\prime} \mathrm{S}, 52^{\circ} 30^{\prime} \mathrm{W}$ & Prestes 2010 (pers. comm.) \\
4 - Floresta Nacional de Irati & $25^{\circ} 21^{\prime} \mathrm{S}, 50^{\circ} 35^{\prime} \mathrm{W}$ & Volpato et al. 2010 \\
5 - Floresta Nacional de Caçador & $26^{\circ} 45^{\prime} \mathrm{S}, 51^{\circ} 11^{\prime} \mathrm{W}$ & IBAMA 2005 \\
6 - Floresta Nacional de Três Barras* & $26^{\circ} 13^{\prime} \mathrm{S}, 50^{\circ} 18^{\prime} \mathrm{W}$ & Present study \\
\hline
\end{tabular}

${ }^{*}$ Indicates reserves where breeding was recorded; Numbers 1-6 refer to the locations in the MF illustrated in Figure 1 .

Our nest observations suggest that, as with other Cyanocorax jays, Azure Jay is a cooperative breeder (Goodwin 1976). Our nest was found in the FNTB in October and was built in a young $A$. angustifolia tree. The incubation period (about 16 days) was similar to the observations made by Anjos (1991). In the present study, the nest was not collected but field observations did not show any differences from the descriptions of other Azure Jay nests (Anjos 1991, Bornschein et al. 1996). For most members of the Cyanocorax genus, only the females are known to incubate, as with the Green Jay C. yncas (Alvarez 1975) and the Tufted Jay C. dickeyi (Crossin 1967). For the Curl-crested Jay C. cristatelus, both males and females briefly replace each other during incubation (Amaral and Macedo 2003). For both the Bushy-crested Jay C. melanocyaneus, and the Brown Jay Psilorhinus morio, two or more individuals were observed incubating the nestlings (Hardy 1976, Lawton and Lawton 1985). Therefore, our observations suggest that the Azure Jay showed a similar behaviour to the Brown Jay and the Bushy-crested Jay, with two individuals incubating. The third bird helped to feed the incubating bird and the nestlings. The vocalisation emitted by the incubating bird before it was fed was the pair call; it was stimulated by the male or the helper. This type of vocalisation (pair call) was also recorded in Curl-crested Jay (Amaral and Macedo 2003), Tufted Jay (Moore 1938) and Brown Jay (Lawton and Lawton 1985). When the helper was not feeding the incubating bird, it worked as a sentinel.

A flock of three individuals of the Azure Jay was observed for almost one year living in a 9 ha patch of primitive mixed rainforest in a region called "Campos Gerais", southern Brazil (Anjos 1991). This region is composed of grassland with small natural patches of MF (a picture of this landscape is found in Anjos and Boçon 1999), indicating that a flock of three Jays could survive in an isolated patch of primary mixed rainforest for one year. Thus, the territory size estimated in the present study for this species in plantations and secondary forest seems to be larger than in primary forest. This difference could be attributed to the potentially lower food availability in the modified areas (plantations and secondary forest), which are structurally less diverse than primary mixed rainforest. The Azure Jay is an omnivorous bird that feeds mainly on seeds of $A$. angustifolia during autumn and winter, consuming arthropods and fruit during spring and summer (Anjos 1991). It is possible that the larger territory found for this species is a way of compensating for the poor food supply. Food items other than seeds may be rare in Araucaria plantations. However, our observations in both the FNTB and FTHO suggest that this species has a high dependence on areas with a higher density of the conifer A. angustifolia.

In the present study, carried out in disturbed areas, we found a significant positive relationship between territory size and the number of individuals in a flock. Supposedly, larger territories are needed for larger flocks, as found in the Florida Scrub Jay Aphelocoma caerulescens (Woolfenden and Fitzpatrick 1984). The fact that the number of individuals per flock was lower in plantations than in secondary forest may be due to recent colonisation; in fact, up until September 2007, the Azure Jay was not recorded in the plantations studied. Five individuals were recorded in one active nest found in the "Campos Gerais" region, although the size of the territory was not documented (Anjos 1995). 
The fact that reproduction was recorded in Araucaria plantations may be a positive factor for the conservation of this species, since the areas of MF are becoming increasingly scarce. Another potential effect may be also positive. In the saturated habitat where the Florida Scrub Jay lives in North America, the number of helpers in flocks tends to increase, due to the absence of new opportunities for territories (see Woolfenden and Fitzpatrick 1984). FTHO may be considered saturated, since two flocks were found in 240 ha, whereas the larger areas of Araucaria plantations may represent new territory opportunities for the species. Such an effect may decrease the number of helpers living in flocks in Araucaria plantations, and then increase the number of offspring per area; in plantations, five flocks were found in about 350 ha. Therefore, Araucaria plantations could be considered a conservation tool for the Azure Jay.

\section{Acknowledgements}

We thank A. Battisti, R. Kurchewski, E. Kurchewski, A. Marques and A. Reis of the staff of Chico Mendes Institute for Biodiversity Conservation (ICMBio) of the Floresta Nacional de Três Barras reserves, who gave permission and provided support for the field work. We thank J. M. Marzluff, who provided helpful reviews and suggestions that substantially improved the first version of the manuscript; we thank P. Atkinson and the anonymous reviewers for comments and suggestions that improved the last version of the manuscript. The first author received a research grant from CAPES (Coordination for the Improvement of Higher Level Personnel, DS) and the second a research grant from $\mathrm{CNPq}$ (Brazilian Council for Development of Science and Technology, 305593/07-3).

\section{References}

Alvarez, H. (1975) The social system of the Green Jay in Colombia. Living Bird 14: 5-44.

Amaral, M. F. and Macedo, R. H. F. (2003) Breeding patterns and habitat use in the endemic Curl-crested Jay of central Brazil. J. Field Ornithol. 74: 331-340.

Anjos, L. (1991) O ciclo anual de Cyanocorax caeruleus em Floresta de Araucária (Passeriformes: Corvidae). Ararajuba 2: 19-23.

Anjos, L. (1995) Gralha-Azul: biologia e conservação. Curitiba, Paraná: Companhia de Seguros Gralha Azul.

Anjos, L. and Boçon, R. (1999) Bird communities in natural forest patches in southern Brazil. Wilson Bull. 111: 397-414.

Anjos, L. and Vielliard, J. M. E. (1993) Repertoire of the acoustic communication of the Azure Jay Cyanocorax caeruleus (Viellot) (Aves, Corvidae). Rev. Bras. Zool. 10: 657664.

Anjos, L., Debus, S., Madge, S. and Marzluff, J. (2009) Family Corvidae. Species accounts. Pp. 566-640 in J. Del Hoyo, A. Elliott and D. Christie, eds. Handbook of the birds of the world. Vol. 14. Barcelona: Lynx Edicions.
Backes, A. (2009) Floresta com Araucárias: Importância e usos múltiplos. Pp. 303-309 in C. R. Fonseca, A. F. Souza, A. M. LealZanchet, T. Dutra, A. Backes and G. Ganado, eds. Floresta com Araucária: Ecologia, conservação e desenvolvimento sustentável. Ribeirão Preto: Holos.

BirdLife International (2000) Threatened birds of the world. Barcelona and Cambridge, UK: Lynx Edicions and BirdLife International.

BirdLife International (2008) Cyanocorax caeruleus. In: IUCN 2010. IUCN Red List of threatened species. Version 2010.4. <www. iucnredlist.org >. (Acessed 24 March 2011).

Bornschein, M. R., Reinert, B. L. and Boçon, R. (1996) Novas informações sobre o ninho e o ovo da gralha-azul Cyanocorax caeruleus (Corvidae). Ararajuba 4: 32-34.

Crossin, R. S. (1967) The breeding biology of the Tufted Jay. Proc. Western Found. Vertebr. Zool. 1: 265-297.

Duca, C., Guerra, T. J. and Marini, M.Â. (2006) Territory size of three Antbirds (Aves, Passeriformes) in an Atlantic Forest fragment in southeastern Brazil. Rev. Brasil. Zool. 23: 692-698. 
Franz, I., Otto, P. H. and Barros, M. P. (2004) Avifauna da Floresta Nacional de Canela, RS: Dados preliminares. In Livro de resumos do XII Congresso Brasileiro de Ornitologia: 22. Santa Catarina: Blumenau.

Goodwin, D. (1976) Crows of the world. Ithaca, NY: Cornell University Press.

Hardy, J. W. (1976) Comparative breeding behavior and ecology of the Bushy-Crested and Nelson San Blas Jays. Wilson Bull. 88: 96-120.

IBAMA (2005) Plano de manejo da Floresta Nacional de Caçador. Brasilia: Ministério do Meio Ambiente: Instituto Brasileiro do Meio Ambiente e dos Recursos Naturais Renováveis (IBAMA).

Indrusiak, C. and Monteiro, S. A. (2009) Unidades de conservação na área de distribuição da Araucária. Pp. 253-265 in C. R. Fonseca, A. F. Souza, A. M. LealZanchet, T. Dutra, A. Backes and G. Ganado, eds. Floresta com Araucária: Ecologia, conservação e desenvolvimento sustentável. Ribeirão Preto: Holos.

IUCN (2010) Red List of threatened species. Version 2010.1. Available at: $<$ http//:www. iucnredlist.org. $>$ (Accessed 27 December 2010).

Jullien, M. and Thiollay, J-M. (1998) Multispecies territoriality and dynamic of Neotropical forest understory bird flocks. J. Anim. Ecol. 67: 227-252.

Koch, Z. and Corrêa, M. C. (2002) Araucária: A floresta do Brasil meridional. Curitiba: Olhar Brasileiro Editora.

Lawton, M. F. and Lawton, R. O. (1985) The breeding biology of the Brown Jay in Monteverde, Costa Rica. Condor 87: 192-204.

Luginbuhl, J. M., Marzluff, J. M., Bradley, J. E., Raphael, M. G. and Varland, D. E. (2001) Corvid survey techniques and the relationship between corvid relative abundance and nest predation. J. Field Ornith. 72: 556-572.

Mendonça, F. A. and Danni-Oliveira, M. I. (2002) Dinâmica atmosférica e tipos climáticos predominantes na Bacia do Rio Tibagi. Pp. 63-66 in M. E. Medri, E. Bianchini, O. A. Shibata and J. A. Pimenta, eds. A bacia do Rio Tibagi. Paraná: Londrina.
Mohr, C. O. (1947) Table of equivalent populations of North American small mammals. Am. Midland Nat. J. 37: 223-249.

Moore, E. R. T. (1938) Discovery of the nest and eggs of the Tufted Jay. Condor 15: 233-241.

Morellato, L. P. C., Talora, D. C., Takahasi, A., Bencke, C. C., Romera, E. C. and Zipparro, V. B. (2000) Phenology of Atlantic rain forest trees: a comparative study. Biotropica 32: 811-823.

Odum, E. P. and Kuenzler, E. J. (1955) Measurement of territory size and home range size in birds. The Auk 72:128-137.

$\mathrm{R}$ Development Core Team (2009) R: A language and environment for statistical computing. Vienna, Austria: R Foundation for Statistical Computing. Available at: http://www.R-project.org. (Accessed oI November 2010).

Ribeiro, B. A., Goulart, M. F. and Marini, M. Â. (2002) Aspectos da territorialidade de Knipolegus lophotes (Tyrannidae, Fluvicolinae) em seu período reprodutivo. Ararajuba 10: 231-235.

Ribeiro, M. C., Metzger, J. P., Martensen, A. C., Ponzoni, F. J., and Hirota, M. M. (2009) The Brazilian Atlantic forest: How much is left, and how much is remaining forest distributed? Implications for conservation. Biol. Conserv. 142: 1141-1153.

Ridgely, R. S. and Tudor, G. (1989) The birds of South America: The oscine passerines Vol. I. Tokyo: Oxford University Press.

Schäffer, W. B. and Prochnow, M. (2002) A mata Atlântica e você: como preservar, recuperar e se beneficiar da mais ameaçada floresta brasileira. Brasília: Apremavi.

Stotz, D. F., Fitzpatrick, J. W., Parker III, T. A. and Moskovits, D. K. (1996) Neotropical birds: Ecology and conservation. Chicago: The University Chicago Press.

Volpato, G. H., Prado, V. M. and Anjos, L. (2010) What can tree plantations do for forest birds in fragmented forest landscapes? A case study in southern Brazil. For. Ecol. Manage. 260: 1156-1163.

Wiktander, U., Olson, O. and Nilsson, S. G. (2001) Seasonal variation in home-range size, and habitat area requirement of the lesser Spotted Woodpecker (Dendrocopos minor) in southern Sweden. Biol. Conserv. 100: 387-395. 
Woolfenden, G. E. and Fitzpatrick, J. W. of a cooperative-breeding bird. Princeton, (1984) The Florida Scrub Jay: demography New Jersey: Princeton University Press.

\section{ANDREA LARISSA BOESING*, LUIZ DOS ANJOS}

Departamento de Biologia Animal e Vegetal, Universidade Estadual de Londrina, Rodovia Celso Garcia Cid, Campus Universitário - Caixa Postal 6001, CEP 86051-980, Londrina, Paraná, Brazil.

*Author for correspondence; e-mail: lari.boesing@gmail.com

Received 2 February 2011; revision accepted 16 June 2011; Published online 4 January 2012 